\title{
Intradural Extramedullary Spinal Cord Metastasis of the Prostate: A Case Presentation and Review of the Literature
}

\author{
Amparo Wolf, Ryan Johnstone, Fawaz Siddiqi
}

\begin{abstract}
Prostate cancer is associated with vertebral metastasis in up to $10 \%$ of patients; however, intradural spinal cord metastases (ISCM) are much less frequent. We present the clinical and histopathological findings of a patient with ISCM arising from prostate. A PubMed literature search for ISCM from the prostate yielded a total of nine additional cases. ISCM of the prostate occurs at a late stage of systemic disease and the prognosis is generally poor. Decompressive surgery followed by adjuvant radiation therapy may help reduce intractable pain and stabilize neurological symptoms, thereby improving quality of life.
\end{abstract}

RÉSUMÉ: Métastases extra-médullaires intradurales à la moelle épinière provenant d'un cancer de la prostate : observation clinique et revue de la littérature. Près de $10 \%$ des patients atteints d'un cancer de la prostate présentent des métastases vertébrales. Cependant les métastases intradurales à la moelle épinière (MIMÉ) sont beaucoup moins fréquentes. Nous présentons les données cliniques et anatomopathologiques d'un patient atteint de MIMÉ provenant d'un cancer de la prostate. Nous avons procédé à une recherche dans PubMed pour identifier les publications portant sur les MIMÉ de la prostate, ce qui nous a permis de retrouver 9 cas additionnels. Les MIMÉ de la prostate surviennent en phase tardive de l'évolution systémique de la maladie et le pronostic à ce stade de la maladie est généralement sombre. La chirurgie de décompression suivie de radiothérapie adjuvante peut aider à atténuer la douleur irréductible ainsi qu'à stabiliser les symptômes neurologiques et donc améliorer la qualité de vie.

Keywords: metastatic tumors, spinal surgery, spinal cord, surgery

doi:10.1017/cjn.2016.43

Can J Neurol Sci. 2016; 43: 588-592

The spine is the third most common site for cancer cells to metastasize, following the lung and the liver. Spinal metastases most often involve the epidural space and/or vertebral column. Intradural extramedullary and intramedullary spread of systemic cancer accounts for only $5 \%$ to $6 \%$ and $0.5 \%$ to $1 \%$ of spinal metastases, respectively. ${ }^{1}$ The most common histological type is adenocarcinoma, most frequently arising from the breast and lung. Adenocarcinoma of the prostate affects up to $70 \%$ of men older than age 80 and is currently the second leading cause of cancerrelated death in men. ${ }^{2}$ Skull and spinal metastases occur in up to $10 \%$ of patients with prostate cancer, ${ }^{3}$ whereas intradural spinal cord tumors arising from the prostate have only rarely been reported. Here, we present a case and review published reports of intradural spinal cord metastasis (ISCM) arising from the prostate.

\section{Case Report}

A 75-year-old Caucasian man presented with progressive back pain and left-sided polyradiculopathy with worsening leg weakness spanning over a 1-year duration. His medical history was relevant for adenocarcinoma of the prostate, diagnosed 5 years prior, with extensive capsular involvement and a Gleason score of 7 . He underwent a radical prostatectomy and salvage radiation treatment. This was followed by hormonal therapy 3 years later and then complete androgen blockade. Magnetic resonance imaging (MRI) of the lumbar spine demonstrated multiple lobulated intradural enhancing lesions at the L5-S1 level, encasing the exiting L5 nerve sheath and extending into the left S1, S2, and $\mathrm{S} 3$ nerve roots (Fig. 1). The patient was brought to the operating room and underwent bilateral L4, L5, and S1 laminectomies. A durotomy followed by a biopsy and partial resection of the intradural lesion were performed. Unfortunately, the tumor was exceedingly adherent to the surrounding nerve rootlets. It was elected to close because any attempt at further resection would likely have resulted in significant neurological morbidity. The biopsy demonstrated metastatic adenocarcinoma, consistent with a prostate primary. The neoplastic cells were arranged in cords and nests with some areas showing a cribriform growth pattern. These cells had hyperchromatic small nuclei with a few with prominent nucleoli, demonstrating positive immunolabeling for prostate-specific antigen and prostate acid phosphatase (Fig. 2). The tumor was negative for CK 7, CK 20, TTF-1, and chromogranin immunoreactivity. Postoperatively, the patient was referred to radiation oncology, at which point he received a total dose of 20 Gy in 5 fractions from L4 to S3 inclusive. At a 3-month follow-up

From the Department of Clinical Neurological Sciences, Division of Neurosurgery, Schulich School of Medicine and Dentistry, University of Western Ontario, London, Ontario, Canada.

Received May 25, 2015. Final Revisions Submitted November 30, 2015. Date of Acceptance February 18, 2016.

Correspondence to: Fawaz Siddiqi, Assistant Professor of Neurosurgery and Orthopedics, University of Western Ontario, Rm E4-128, Victoria Hospital, 800 Commissioners Rd., London, Ontario, Canada N6A 5W9. Email: amparo.wolf@gmail. com 


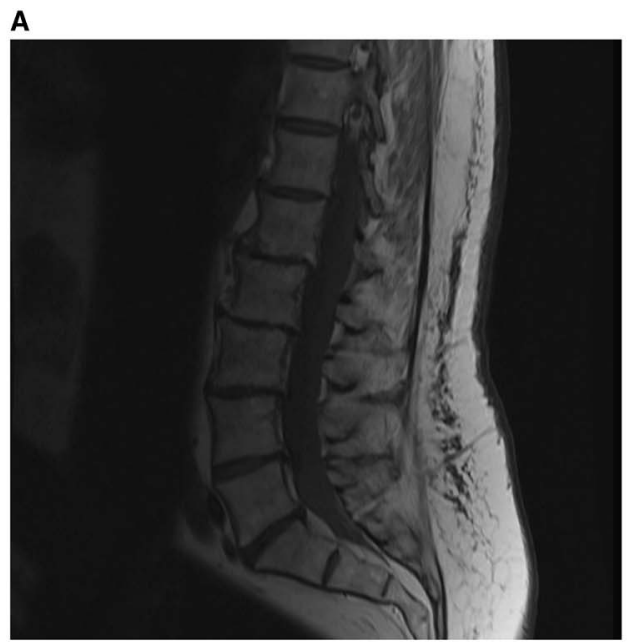

c

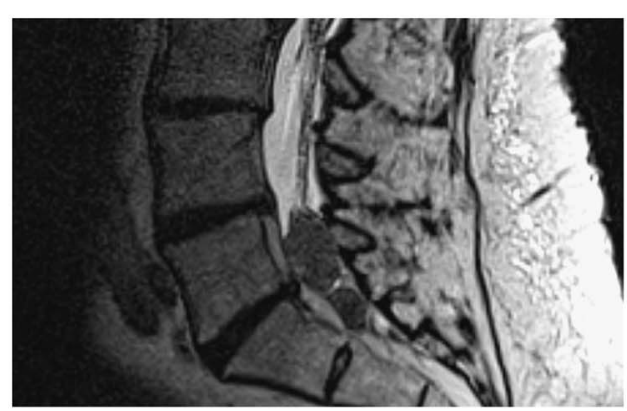

B

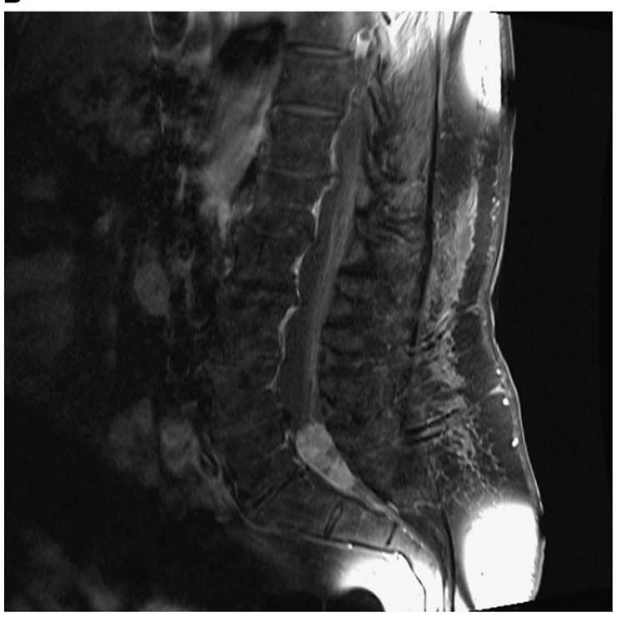

D

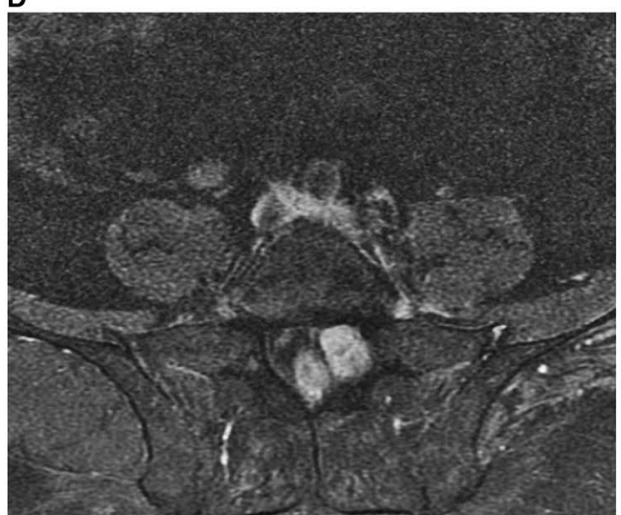

Figure 1: Preoperative magnetic resonance imaging (MRI) scan showing intradural lesion at L5-S1, with extension into left L5 and S1 nerve roots. (A) Sagittal T1-weighted MR1 scan. (B) Sagittal T1-weighted MRI scan with gadolinium. (C) Sagittal T2-weighted MRI scan. (D) Axial T1-weighted MRI scan with gadolinium.

visit, the patient reported feeling increased strength in his left leg with improved ambulation.

\section{Discussion}

Approximately $10 \%$ of patients with prostate carcinoma may develop spinal cord compression from vertebral metastasis. ${ }^{3,4}$ Focal intradural prostatic spinal cord metastasis is rare. We identified only nine published case reports of patients with prostate ISCM having undergone surgery, including this report, from an extensive PubMed English literature search (Table 1).

Prostate ISCM has shown a preponderance to metastasize to the lumbosacral region. ${ }^{4}$ A meta-analysis of more than 284 patients with ISCM, none of whom had prostate as a primary, reported proportions of $42 \%$ cervical, $26 \%$ thoracic, and $32 \%$ lumbar. ${ }^{5}$ The predilection to different regions of the spinal cord may potentially reflect differences in pathophysiology of ISCM depending on the primary cancer. Putative mechanisms of spread to the intradural extramedullary spinal compartment include hematogenous spread, direct extension from the epidural space, spread along perineural lymphatics, drop metastasis, and dissemination by cerebrospinal fluid (CSF).
Intradural extramedullary metastases may be a form of focal leptomeningeal carcinomatosis by spreading through CSF pathways. This hypothesis is supported by the fact that the incidence of associated cerebral metastasis has been reported as high as $50 \%$ to $80 \%$ in patients with ISCM. ${ }^{1,4,6}$ The percent of associated cerebral metastasis may be lower in prostatic metastasis. As depicted in Table 1, only two of seven cases (28.5\%) of prostatic ISCM were associated with cerebral metastasis.

Symptoms leading to the diagnosis of ISCM typically include back and/or leg pain in the setting of rapidly progressive neurological deficits. It may be difficult to distinguish extradural and intradural lesions initially based on clinical symptoms. A differentiating feature of ISCM with extradural metastasis is that the latter presents with predominant back pain with the development of neurological symptoms occurring at a later time. ${ }^{7}$ On the other hand, intradural metastases may present with back pain in conjunction with neurological symptoms such as unilateral motor or sensory disturbance. ${ }^{7}$ Back pain when recumbent tends to be more common in cases of intradural disease, especially with lesions involving the cauda equina. ${ }^{8}$

The diagnosis of prostate ISCM may be difficult to establish early on and may require serial MRIs during a period of 

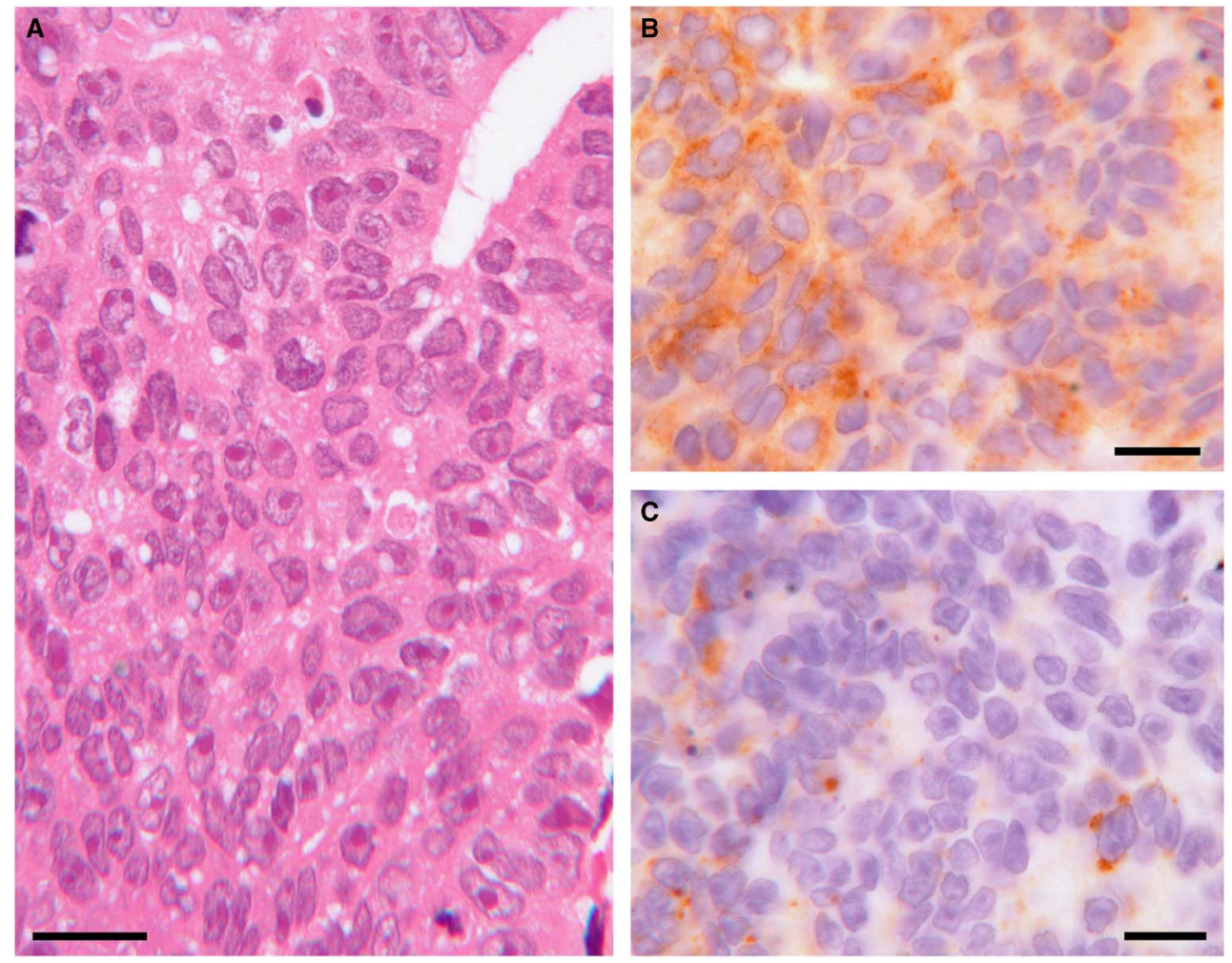

Figure 2: Histological appearance of the patient's intradural spinal cord metastasis. (A) Hematoxylin and eosin. (B) Immunohistochemical staining revealed a positive reaction to prostate secretory protein. (C) Prostatic acid phosphatase (scale $=20$ microns).

increasingly severe radicular pain. The MRI scan characteristics of a single metastatic lesion may also be identical to that of schwannoma; therefore, a history of rapid clinical progression or multiple lesions on MRI may be required to establish the diagnosis of metastatic disease in the absence or if a remote history of a primary cancer. ${ }^{4}$ CSF cytology may show evidence of malignant cells. ${ }^{4}$ Elevated prostatespecific antigen in the CSF may assist in diagnosing ISCM of the prostate according to one study. ${ }^{9}$

Most patients who develop ISCM are in the advanced stages of their disease. The mean survival after diagnosis of ISCM arising from a variety of primary cancers (lung, breast, melanoma, etc.) may range between 4 and 7 months. ${ }^{1,10}$ The few studies that have looked at postoperative outcomes in ISCM have reported no significant or minimal improvement in survival. ${ }^{1,5,6}$ Prior reports have concluded that degree of resection in ISCM does not predict survival. ${ }^{10,11}$ However, surgery may be recommended in the context of uncertain diagnosis. Furthermore, studies have reported a benefit of surgery with respect to symptoms of intractable pain and stabilization and/or improvement of neurological symptoms. ${ }^{12-14}$ All of the studies listed in Table 1 attempted surgical resection of prostate ISCM. Most of these studies reported performing a partial resection because of significant involvement and adherence of the tumor to nerve roots of the cauda equina, aside from the two intramedullary cases. ${ }^{15,16}$ Clinical follow-up ranging between 3 and 18 months was available on seven patients. One patient passed away from cerebral metastasis, whereas one patient continued to deteriorate. Five of the seven patients had improved pain and/or remained neurologically stable at a mean follow-up of 4 months. Based on these reports, palliation of severe pain or attempts to stabilize neurological function or maintain ambulatory status may be indications for surgery. In our case study, surgery was recommended to confirm the diagnosis and attempt to prevent further neurological decline.

There are no established guidelines on the management of ISCM mainly because of its rarity. With improvements in systemic therapies and increased patient survival, ISCMs will present with increasing frequency. Treatment options include surgery, conventional radiotherapy, stereotactic radiosurgery, and chemotherapy. Although the number of reported studies on the surgical treatment of ISCM is small, the literature to date supports a role for this treatment approach in some patients. ${ }^{12,14} \mathrm{An}$ aggressive approach aiming for gross total resection may be warranted for extramedullary lesions. This would serve to decompress neural structures thereby improving intractable pain, limb weakness, and/or bowel and bladder dysfunction. For tumors that lack a cleavage plane or are embedded with the cauda equina, only biopsy or debulking surgery with decompressive laminectomy may be possible. These cases may benefit from a palliative course of adjuvant fractionated radiotherapy or more targeted stereotactic radiosurgery.

\section{CONCLUSIONS}

Metastases to the spinal intradural space are rare and typically occur late in the course of prostate cancer. Surgery may be indicated for those patients who can tolerate the procedure, who have intractable pain, or who are at risk of permanent loss of 
Table 1: Summary of published reports of intradural spinal cord prostate metastasis

\begin{tabular}{|c|c|c|c|c|c|c|c|c|c|c|c|}
\hline Author/Year & Age & $\begin{array}{l}\text { Spine } \\
\text { Level }\end{array}$ & $\begin{array}{c}\text { TNM/ } \\
\text { Gleason } \\
\text { Score }\end{array}$ & Signs/Symptoms & $\begin{array}{c}\text { EM/ } \\
\text { IM }\end{array}$ & $\begin{array}{c}\text { Other } \\
\text { Prostate Mets }\end{array}$ & $\begin{array}{c}\text { Time to } \\
\text { ISCM } \\
\text { (Months) }\end{array}$ & Surgery & $\begin{array}{l}\text { Radiation to } \\
\text { Spine }\end{array}$ & $\begin{array}{l}\text { CSF } \\
\text { for } \\
\text { PSA }\end{array}$ & Follow-up (Months) \\
\hline $\begin{array}{l}\text { Kuban et al, } \\
1986\end{array}$ & NR & NR & NR & NR & EM & NR & NR & NR & Chemo, RT & NR & NR \\
\hline $\begin{array}{l}\text { Stambough } \\
\text { et al, } 1991\end{array}$ & 54 & $\begin{array}{l}\text { L3-S1 } \\
\text { nerve } \\
\text { roots }\end{array}$ & NR & $\begin{array}{l}\text { Pain, left LE weakness, diminished } \\
\text { sensation below L3 }\end{array}$ & EM & None & NR & PR & RT & NR & $\begin{array}{l}6 \text { months; reduced pain; } \\
\text { neurologically stable }\end{array}$ \\
\hline $\begin{array}{l}\text { Schaller et al, } \\
1998\end{array}$ & 79 & L5-S3 & T3-T4 & $\begin{array}{l}\text { Left lumbosacral radicular pain, left LE } \\
\text { weakness, hyperalgesia }\end{array}$ & EM & None & 24 & PR & $\begin{array}{l}\text { Preoperative } \\
\text { RT (32 Gy) }\end{array}$ & $\begin{array}{l}29.1 \mathrm{ng} / \\
\mathrm{ml}\end{array}$ & 18 months; continued deterioration \\
\hline $\begin{array}{l}\text { Frey et al, } \\
1998\end{array}$ & 63 & NR & NR & NR & EM & None & NR & NR & NR & NR & NR \\
\hline $\begin{array}{l}\text { Hentschel } \\
\text { et al, } 2004\end{array}$ & 60 & L1-L2 & NR & Back pain, paresthesia LEs & EM & $\begin{array}{l}\text { Multiple brain } \\
\text { mets }\end{array}$ & 84 & PR & $\begin{array}{l}\mathrm{RT} \text { ( } 30 \mathrm{~Gy}, 12 \\
\text { fractions) }\end{array}$ & NR & $\begin{array}{l}4 \text { months; death from intracranial } \\
\text { mets }\end{array}$ \\
\hline $\begin{array}{l}\text { Deinsberger } \\
\text { et al, } 2006\end{array}$ & 61 & T10-S1 & NR & Sensory loss at $\mathrm{T} 9$, progressive paresis LEs & EM & None & 42 & PR & RT (50.4 Gy) & NR & $\begin{array}{l}6 \text { months; ambulatory, } \\
\text { neurologically stable }\end{array}$ \\
\hline $\begin{array}{l}\text { Lieberson } \\
\quad \text { et al, } 2012\end{array}$ & 68 & T12, L1 & 7 & $\begin{array}{l}\text { Numbness, saddle anesthesia, fecal } \\
\text { incontinence }\end{array}$ & IM & $\begin{array}{l}\text { Cerebral } \\
\text { (fourth } \\
\text { ventricle) }\end{array}$ & 15 & TR & RS & NR & 3 months; neurologically stable \\
\hline $\begin{array}{l}\text { Wu et al, } \\
2014\end{array}$ & 74 & $\mathrm{~T} 12$ & NR & $\begin{array}{l}\text { Back pain, numbness and progressive } \\
\text { paresis LE, sphincter dysfunction }\end{array}$ & $\mathrm{IM}$ & Bone mets & NR & TR & Chemo & NR & Ambulatory, neurologically stable \\
\hline $\begin{array}{l}\text { Wolf et al, } \\
2016\end{array}$ & 75 & L4-S3 & $\mathrm{T} 3 \mathrm{~b} / 7$ & $\begin{array}{l}\text { Progressive left leg weakness and left leg } \\
\text { radicular pain }\end{array}$ & EM & None & 60 & PR & $\begin{array}{l}\mathrm{RT}(20 \mathrm{~Gy}, 5 \\
\text { fractions) }\end{array}$ & NR & $\begin{array}{l}3 \text { months; ambulatory; improved } \\
\text { pain; neurologically stable }\end{array}$ \\
\hline
\end{tabular}

EM, extramedullary; IM, intramedullary; LE, lower extremities; mets, metastases; NR, not reported; NS, no surgery; PR, partial resection; PSA, prostate-specific antigen; RS, radiosurgery;

$\mathrm{RT}$, radiation therapy; TR, total resection. 
neurological function. Recommendation of surgery in those circumstances would be to confirm the diagnosis and to improve the quality of life in those with intractable pain and nerve root or cord compression, taking into account the general medical condition of the patient and the presence of multiple sites of metastases or leptomeningeal spread. Surgery may not be able to achieve gross total resection, but can act as an adjunct to radiation therapy.

\section{ACKNOWLEDGMENTS}

The authors thank Dr. David Ramsay for providing neuropathological assistance for the clinical case described in this report.

\section{Disclosures}

The authors have nothing to disclose.

\section{REFERENCES}

1. Chow TS, McCutcheon IE. The surgical treatment of metastatic spinal tumors within the intradural extramedullary compartment. J Neurosurg. 1996;85:225-30.

2. Haas GP, Delongchamps N, Brawley OW, Wang CY, de la Roza G. The worldwide epidemiology of prostate cancer: perspectives from autopsy studies. Can J Urol. 2008;15:3866-71.

3. Osborn JL, Getzenberg RH, Trump DL. Spinal cord compression in prostate cancer. J Neurooncol. 1995;23:135-47.

4. Frey I, Le Breton C, Lefkopoulos A, et al. Intradural extramedullary spinal canal secondary neoplasms: MR findings in 30 patients. Eur Radiol. 1998;8:1187-92.

5. Kalayci M, Cagavi F, Gul S, Yenidunya S, Acikgoz B. Intramedullary spinal cord metastases: diagnosis and treatment - an illustrated review. Acta Neurochir (Wien). 2004;146:1347-54.
6. Perrin RG, Livingston KE, Aarabi B. Intradural extramedullary spinal metastasis. A report of 10 cases. J Neurosurg. 1982;56: 835-7.

7. Stambough JL, Reid JH, Ross MA, Simeone FA, Booth RE. Isolated intradural metastasis simulating lumbar disc disease. Spine (Phila Pa 1976). 1991;16:581-3.

8. McCormick PC, Post KD, Stein BM. Intradural extramedullary tumors in adults. Neurosurg Clin N Am. 1990;1:591-608.

9. Schaller B, Merlo A, Kirsch E, et al. Prostate-specific antigen in the cerebrospinal fluid leads to diagnosis of solitary cauda equina metastasis: a unique case report and review of the literature. Br J Cancer. 1998;77:2386-9.

10. Wilson DA, Fusco DJ, Uschold TD, Spetzler RF, Chang SW. Survival and functional outcome after surgical resection of intramedullary spinal cord metastases. World Neurosurg. 2012;77:370-4.

11. Gasser T, Sandalcioglu IE, El Hamalawi B, van de Nes JA, Stolke D, Wiedemayer H. Surgical treatment of intramedullary spinal cord metastases of systemic cancer: functional outcome and prognosis. J Neurooncol. 2005;73:163-8.

12. Wostrack M, Pape H, Kreutzer J, Ringel F, Meyer B, Stoffel M. Surgical treatment of spinal intradural carcinoma metastases. Acta Neurochir (Wien). 2012;154:349-57.

13. Hentschel SJ, Mendel E, Singh S, Rhines LD. Metastatic prostate carcinoma to the intradural extramedullary spinal compartment. Case report. J Neurosurg. 2004;100:375-7.

14. Hoover JM, Krauss WE, Lanzino G. Intradural spinal metastases: a surgical series of 15 patients. Acta Neurochir (Wien). 2012;154: 871-7.

15. Lieberson RE, Veeravagu A, Eckermann JM, et al. Intramedullary spinal cord metastasis from prostate carcinoma: a case report. J Med Case Rep. 2012;6:139.

16. $\mathrm{Wu} \mathrm{Z}, \mathrm{Xu} \mathrm{S}$, Zhong $\mathrm{C}$, et al. Intramedullary conus medullaris metastasis from prostate carcinoma: a case report and review of the literature. Oncol Lett. 2014;7:717-20. 